\title{
A study of growth responses to nutrient inputs by modelling
}

\section{By C. T. Whiтtemore, Department of Agriculture, University of Edinburgh,} West Mains Road, Edinburgh EH9 $3 \mathfrak{F G}$

The potential of models in the pursuit of understanding and predicting animal responses to nutrient inputs was shown by Miller \& Payne (1963). A model can be a combination of available experimental findings, corroborative circumstantial evidence, and assumption; as such it is no better than its components. Growth responses determined from an integrated model have little validity in their own right. The importance of demonstrating effective simulation is in the credibility that accrues thereby to the construction.

Given below are the source equations of a model which has been used at Edinburgh to simulate growth responses of pigs over the weight range $20-120 \mathrm{~kg}$ (Whittemore \& Fawcett, 1974; 1975a,b; 1976; Whittemore, 1976; Whittemore \& Elsley, 1976). These equations have been validated by comparison with results from controlled feeding trials, which confirm that pig growth is effectively simulated.

Growth responses by modelling are therefore best studied by an examination of the elements of the model, rather than by obtaining output from it. Output may, in any event, be regenerated from the source equations given.

\section{A model for pig growth}

The derivation of these equations is discussed by Whittemore \& Fawcett ( 1976 ).

Input: DCP (digestible crude protein); DE (digestible energy); V (chemical score of protein); Pr̂ (inherent limit to protein accretion); $T$ (house temperature); $N$ (score for insulation, draughts and bedding); LW (live weight at start); LWF (live weight at slaughter).

\section{Programme}

$\mathrm{Pt}$ (protein at start) $=0.154 \mathrm{LW}-0.212$

Lt (lipid at start) $=0.192 \mathrm{LW}-0.288$

At (ash at start) $=0.032 \mathrm{LW}-0.073$ (Interpolated from Wood \& Groves, 1965)

EBW (empty body weight) $=0.952 \mathrm{LW}$

MBW (metabolic body weight) $=\mathrm{LW}^{0.75}$

$F$ (feed intake) $=7.5-8 \cdot 267 \mathrm{e}^{-0.010 \mathrm{LW}}$ or $0.5+0.033^{\mathrm{LW}}$ or $0.10 \mathrm{MBW}$ or $\mathrm{I} \cdot 0+0.025$ (days) or any other

Epf (protein free DE) $=\mathrm{DE}-23.6 \mathrm{DCP}$

$\mathrm{Pf}$ (mature protein mass) $=660 \mathrm{P} \hat{\mathbf{r}}-35$ 
$\mathrm{Pr} / \mathrm{Px}$ (protein accretion/protein synthesis) $=0.23(\mathrm{Pt}-\mathrm{Pt}) / \mathrm{Pt}$

$\mathrm{P}($ protein intake $)=(\mathrm{F})(\mathrm{DCP})$

$\operatorname{Pr}=(\mathrm{F})(\mathrm{DCP})(\mathrm{V}) /[0.94+(0.06 /(\mathrm{Pr} / \mathrm{Px}))]$

If $\operatorname{Pr}>\operatorname{Pr}$ then $\operatorname{Pr}=\operatorname{Pr}$

$E$ (energy intake $)=(F)(D E)$

$\mathrm{Px}=\mathrm{Pr} /(\mathrm{Pr} / \mathrm{Px})$

If $\mathrm{Px}<0.05 \mathrm{Pt}$ then $\mathrm{Px}=0.05 \mathrm{Pt}$

$\varphi \mathrm{Pb}$ (endogenous protein losses) $=0.06(\mathrm{Px}-\mathrm{Pr})$

USP (protein not used $)=\mathrm{P}-(\mathrm{Pr}+\varphi \mathrm{Pb})$

$\mathrm{Pm}$ (protein deaminated $)=\mathrm{USP}+\varphi \mathrm{Pb}$

EU (energy in urine) $=7 \cdot 2 \mathrm{Pm}$

$\mathrm{ME}$ (classical metabolizable energy) $=\mathrm{E}-\mathrm{EU}$

Q (available ME) $=(\mathrm{Epf})(\mathrm{F})+\mathrm{II} \cdot 5 \mathrm{Pm}+23.6 \mathrm{Pr}$

$\mathrm{Em}$ (energy cost of maintenance) $=0.475 \mathrm{MBW}-[7.3(0.05 \mathrm{Pt})]$

EPr (energy cost of protein accretion) $=7 \cdot 3 \mathrm{Px}+23 \cdot 6 \mathrm{Pr}$

$\mathrm{Lr}$ (lipid accretion) $=\left[\mathrm{Q}-\left(\mathrm{Em}+\mathrm{EPr}+\mathrm{H}^{1}\right) V_{53} \cdot 4\left(\mathrm{H}^{1}=\right.\right.$ energy cost of cold thermogenesis)

If $\mathrm{Lr}<\mathrm{Pr}$ then $\mathrm{Pr}=\mathrm{Pr}-\mathrm{Io}$; loop

$\hat{\mathrm{H}}$ (heat output) $=\mathrm{ME}-(23 \cdot 6 \mathrm{Pr}+39 \cdot 3 \mathrm{Lr})$ (Excluding cold thermogenesis)

$\mathrm{T}=\mathrm{TN}$

Tc (critical temperature) $=26 \cdot 6-0.59 \mathrm{H}$

$\mathrm{H}^{\mathrm{l}}=0.016 \mathrm{MBW}(\mathrm{Tc}-\mathrm{T})$; loop

$\mathrm{H}$ (heat output) $-\mathrm{H}+\mathrm{H}^{1}$

$\mathrm{Mg}$ ('lean' gain) $=\operatorname{Pr}(5 \cdot \mathrm{I}-0.00 \mathrm{WW})$ ('lean' = protein + protein associated water; interpolated from Kotarbinska (1969))

$\mathrm{Fg}$ ('fat' gain) = I. I Lr ('fat' = fat + associated water)

Ag ('ash' gain) $=0.215 \mathrm{Pr}$

EBWG (empty body weight gain) $=\mathrm{Mg}+\mathrm{Fg}+\mathrm{Ag}$

LWG (live weight gain) $=\mathrm{EBWG}+0.05 \mathrm{EBWG}$

EFC (efficiency of feed conversion) $=$ LWG $/ F$

EEC (efficiency of retention of DE) $=(23.6 \mathrm{Pr}+39 \cdot 3 \mathrm{Lr}) / \mathrm{E}$

$E P C$ (efficiency of retention of $D C P$ ) $=\mathrm{Pr} / \mathrm{P}$

$L W=L W+L W G$

$\mathrm{Pt}$ (total protein in empty body) $=\Sigma \mathrm{Pr}+\mathrm{Pt}$

$\mathrm{Lt}$ (total lipid in empty body) $=\Sigma \mathrm{Lr}+\mathrm{Lt}$

At (total ash in empty body) $=\Sigma \mathrm{Ag}+\mathrm{At}$

Md (dissected lean in carcass sides) $=2.53 \mathrm{Pt}$

$\mathrm{Fd}$ (dissected fat in carcass sides) $=0.559 \mathrm{Lt}+4.90$

Bd (dissected bones in carcass sides) $=2.57 \mathrm{At}$

$\mathrm{C}$ (backfat (mm) at C) $=\mathrm{I} \cdot 30 \mathrm{Fd}$

$\mathrm{P}_{2}$ (backfat $(\mathrm{mm})$ at $\left.\mathrm{P}_{2}\right)=0.80 \mathrm{C}+4.0$ (Dissection and backfat predictions calculated from data of R. Braude and J. S. P. Costa (private communication) and Okwuosa (197I) and A. J. Kempster (private communication)) 


\section{Model components}

Protein accretion. Protein accretion is sigmoidal with time: the daily rate ( $\mathrm{Pr})$ increasing in early life and decreasing as the asymptote of mature protein mass $(\mathrm{Pt})$ is reached. From twenty investigations quoted by Thorbek (1975), the following quadratic function fits the data over the live weight range $5-170 \mathrm{~kg}: \operatorname{Pr}=1 \cdot 63$ $\mathrm{LW}-0.0094 \mathrm{LW}^{2}+60$. For white breeds of pig, accretion diminishes at about $80-130 \mathrm{~kg}$ live weight $(0.5 \mathrm{Pt})$ (Oslage, Fliegel, Farries \& Richter, 1966; Kielanowski, 1969; Thorbek, 1975). It is also evident that even during active growth from 20-120 kg there must be some inherent limit to the daily rate of protein accretion (Pr̂); response to protein supply $(\mathrm{P})$ being non-linear. The relationship: $\operatorname{Pr}=0.74 \mathrm{P}-0.0072 \mathrm{P}^{2}$ may be interpolated from data of Rérat \& Henry (1964). For the fowl, Velu \& Baker (1974) expressed the response in terms of a broken line; linear $(\mathrm{Pr}=0.74 \mathrm{P})$ until the requirement for maximal protein retention was reached $(\mathrm{Pr}=\mathrm{P} \hat{r})$, when additional increments of protein effected no increment in retention.

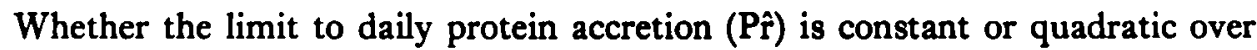
the growth phase relevant to pig-meat production (20-120 kg) is contentious. Daily protein accretion has been shown to increase between $20 \mathrm{~kg}$ and $30-60 \mathrm{~kg}$ live weight (Wenk \& Schürch, 1974; Cöp, 1974; Thorbek, 1975), but it is not clear whether this is expression of a gradually lifting boundary for Pr̂ or the result of an improving nutrient intake. The latter possibly leads to the view that Pr is broadly constant during most of the growing phase; attained at $20 \mathrm{~kg}$ and maintained until r 20 kg (Møllgaard, 1955; Oslage \& Fliegel, r965; Kielanowski, 1969; Rérat, 1972; Whittemore \& Fawcett, 1976). Pr̂ clearly differs between sex and genotype. Purported limits for the three sexes are, $100 \mathrm{~g}$ for castrated males, $112 \mathrm{~g}$ for females and $13 \circ \mathrm{g}$ for entire boars (Piatkowski \& Jung, 1966; Kielanowski, 1969). It is generally accepted that the lean tissue growth rate of entire boars is greater than that of females, as evidenced by faster growth and leaner carcasses. Genotypic limits of $80 \mathrm{~g}$ protein accretion daily for 'unimproved' pigs, $110 \mathrm{~g}$ for 'meat-type' pigs and $\mathrm{I} 30 \mathrm{~g}$ for 'exceptionally fast growers' are suggested by Kielanowski (1969). Selection in Danish Progeny Test Stations was shown to have effected an improvement in $\operatorname{Pr}$ of $14 \mathrm{~g}$, from 79 to $93 \mathrm{~g}$, over a period of 30 years (Kielanowski, r $966 a$ ). In a comparison of ten strains of pigs (Meat and Livestock Commission, 1975), carcass lean growth rates ranged from 226 to $271 \mathrm{~g}$ daily. The relationship between dissected lean in carcass and protein in total body approximates to a factor of 2.53 (calculated from findings of R. Braude and J. S. P. Costa (private communication), and Okwuosa (1971)); it may thus be estimated that Pr ranged from $8 \mathrm{~g}$ to $107 \mathrm{~g}$.

Whittemore \& Fawcett (1976) proposed $\operatorname{Pr}$ to be related to the rate of total protein synthesis $(\mathrm{Px})$ by the equation: $\mathrm{Pr} / \mathrm{Px}=0.23(\mathrm{Pt}-\mathrm{Pt}) / \mathrm{Pt}$, where $\mathrm{Pt}$ is current protein mass and $\mathrm{Pt}$ mature protein mass. The expression $\mathrm{Pr} / \mathrm{Px}$ decreases as maturity is approached. As the energy cost of protein accretion relates to $\mathbf{P x}$ rather than $\mathrm{Pr}$, then the energetic efficiency of protein growth decreases with increasing maturity, but, at any given proportion of maturity, is not affected by the 
value for Pr. Analysis of comparative slaughter trials (Kotarbiniska, 1969; Kielanowski \& Kotarbinska, 1970; Kielanowski, 1972; Müller \& Kirchgessner, 1974; Houseman \& McDonald, 1973; Burlacu, Băia, Ionilă, Moisa, Taşcenco, Vişan \& Stoica, 1973) also suggests that younger pigs have lower energy costs for protein accretion; total energy cost/kg protein formed, inclusive of heat of combustion $(M J)=44 \cdot 5+0.384 \mathrm{LW}$. Energetic efficiency will therefore only improve if $\mathrm{Pt}$ is increased relative to $\mathrm{Pt}$ at slaughter. Determinations of mature protein mass $(\mathrm{P} \hat{t})$ for pigs are scarce, but there are some results (M. Kotarbiniska, unpublished) which suggest values of $35^{-45} \mathrm{~kg}$ for sows and $5^{\circ} \mathrm{kg}$ for boars. Further, if different genotypes or sexes were to reach the same proportion of maturity at similar ages, it is axiomatic that an increase in P $\hat{r}$ will lead to a greater value for $\mathrm{Pf}$. Assuming values of $\mathrm{Pf}$ for castrated boars, females and entire boars to be about 30,40 and $50 \mathrm{~kg}$ respectively, then $\mathrm{Pt} / \mathrm{Pr}$ would approximate to 300,357 , and 385 ; and the general equation, $\mathrm{Pf}=660 \mathrm{P} \hat{\mathbf{r}}-35$. Although it seems unlikely that differences in age at maturity could be of sufficient magnitude to accommodate the range of values suggested in Pr such that they could be attained at the same value of $\mathrm{PE}$, it is apparent that the relationship between $\mathrm{Pt}$ and $\mathrm{Pr}$ justifies further attention.

The relationship between $\operatorname{Pr}$ and total protein synthesis $(P x)$ is crucial to energetic efficiency; Px demanding by far the higher proportion of the energy used for protein growth (Millward, Garlick, James, Sender \& Waterlow, 1976; Buttery \& Boorman, 1976). The energy cost of protein synthesis is probably within the range 5.6-9. I MJ $/ \mathrm{kg}$ (calculated from Armstrong, 1969). Millward et al. (1976) suggest $5.9 \mathrm{MJ} / \mathrm{kg}$ and Whittemore \& Fawcett (1976) use an average value of 7.3 $\mathrm{MJ} / \mathrm{kg}$. The ratio $\mathrm{Pr} / \mathrm{Px}$ has been suggested above to be a function of the proportion of mature protein mass attained, and for average pigs would be about 0.21 at $20 \mathrm{~kg}$ and 0.11 at $120 \mathrm{~kg}$. It is implicit that a change in $\mathrm{Pr}$ effects a proportional change in $\mathrm{Px}$ (the proportion depending upon $\mathrm{Pt}$, the protein mass); similar was argued by Kielanowski (1976). Again, Millward et al. (1976) demonstrated a relationship between protein intake and protein flux.

While the simple relationship for $\mathrm{Pr} / \mathrm{Px}$ may be adequate over a normal range of active rates of growth, it is inadequate to explain the situation at or around maintenance when $\mathrm{Pr}=0$, but $\mathbf{P x}$ has a significant value (suggested to be around $0.05 \mathrm{Pt}$ ). Further, the proposition that an increase in $\mathrm{Pr}$ will effect an increase in metabolic activity mediated through the rate of Px should not obviate the possibility that the maintenance level of protein synthesis may be sufficient to support protein accretion, with no concomitant increase in Px, when the value for $\operatorname{Pr}$ is small. Were this latter the case, then protein accretion may be energetically more efficient when metabolic rate is high and $\mathrm{Pr}$ is small in relation to $\mathrm{P} \hat{\mathbf{r}}$, i.e. in the immature animal.

Protein quality. The amount of dietary protein available for protein accretion depends upon the amino acid content of absorbed protein in relation to the requirements for new protein synthesis $(\mathrm{Pn}) . \mathrm{Pn}=\mathrm{Pr}+\varphi \mathrm{Pb}$, where $\mathrm{Pb}$ is protein breakdown and $\varphi$ the proportion of protein breakdown which is unavoidably lost 
as a result of the inefficiencies of turnover. If $\operatorname{Pr} / \mathrm{Px}=0.15$ (see earlier) and $\varphi=0.06$, it may be calculated that if $\mathrm{Pr}=100 \mathrm{~g}$ then $\varphi \mathrm{Pb}=34 \mathrm{~g}$. Thus, of the total amino acids required, about 0.33 are involved in protein maintenance and 0.66 in protein accretion.

Where the requirement for amino acids is expressed in terms of protein of a particular amino acid mix, then a biological value of unity represents the ideal amino acid balance. For purposes of protein accretion this might be expected to be similar to the amino acid profile to be found in the protein of the whole body of the pig. The critical role of methionine in protein re-synthesis (Lubaszewska, Pastuszewska \& Kielanowski, 1973) suggests that a rather higher proportion of sulphur amino acids might be needed for maintenance than would be provided from labile body protein.

Maintenance. The confusing relationship between maintenance costs and energy used for protein synthesis is apparent when maintenance is determined by statistical apportionment; values usually varying inversely, while the estimate for the energy cost of fat deposition is much less variable (for example, see Houseman \& McDonald, 1973, Burlacu et al. 1973; Thorbek, r975). Neither is the position improved by determination of the basal metabolic rate, on account of the animal adjusting to the condition of fast (Holmes \& Breirem, 1974; Millward et al. 1976). Close \& Mount (1975) found that minimum fasting heat loss $\left(0.380 \mathrm{MJ} / \mathrm{kg} \mathrm{LW}^{0.75}\right)$ was only some 0.80 of maintenance energy requirement $\left(0.475 \mathrm{MJ} / \mathrm{kg} \mathrm{LW}^{0.73}\right)$.

Energy used for maintenance is not a linear function of live weight; tending to a decreasing proportion as weight increases. The appropriate exponent is still not resolved. Breirem (1939) favoured 0.57, while Kielanowski (1972) and Verstegen, Close, Start \& Mount (1973), for example, used the Kleiber value of 0.75 . It is possible that no single exponent adequately describes the data over the range 20-120 kg; neither may live weight be the appropriate variable.

Whichever exponent is used, the coefficient appears to decrease with age (Breirem, 1939; Thorbek, 1974; Gädeken, Oslage \& Fliegel, 1974). Equally a different exponent might apply; unity being appropriate at $20 \mathrm{~kg}$, falling to around 0.5 for pigs heavier than $60 \mathrm{~kg}$ (Mount \& Holmes, 1969; Verstegen, 1971). Taken together, these estimates suggest the exponent (b), over the range $20-70 \mathrm{~kg}$, to be related to live weight by the equation: $b=1 \cdot 24-0.011 \mathrm{LW}$, which indicates an average for $60 \mathrm{~kg}$ of around 0.58 . It is apparent, however, that if a relationship between the requisite exponent and live weight is to be derived, it is likely not to be linear.

A significant proportion of maintenance costs probably result from protein turnover; 0.24 at $20 \mathrm{~kg}$ and $0.3^{6}$ at $120 \mathrm{~kg}$ have been suggested (Whittemore \& Fawcett, 1976). Millward et al. (1976) also allude to the high proportion of basal energy expenditure which can be apportioned to protein turnover. A study of the basal metabolic rate in young sheep (Graham, Searle \& Griffiths, 1974) led to the suggestion that an exponent of unity could be appropriate if the fat-free body mass, rather than live weight, were used. Unity was also suggested for the young pig. It is a characteristic of the pig that it contains little fat when young (about I fat: I 
protein at $20 \mathrm{~kg}$ ), but accumulates fat with increasing rapidity as it grows (about 3 fat: I protein at $100 \mathrm{~kg}$ ) and so it might be surmised that maintenance may be more properly a function of protein mass rather than live weight. In this respect, regression analysis of growth of protein mass between 20 and $120 \mathrm{~kg}$, with dry matter mass (fat + protein +ash) as the independent variable indicates an exponent of 0.66 .

There is limited evidence that maintenance requirement could differ between breeds. On the basis of performance and carcass results from comparative slaughter trials; Saddleback pigs appeared to use less energy for maintenance than white pigs (Okwuosa, 1971), Lacombe less than Yorkshire (Sharma, Young \& Smith, 1971), and Duroc less than Landrace (Fuller, Yen \& Lin, 1974). In each of these three cases the animals with the lower maintenance requirement were also fatter; it appears uncertain as to whether the increased fat resulted from the energy saving or was the cause of it.

Reported values for the energy cost of maintenance range from $0.40 \mathrm{MJ} / \mathrm{kg}$ $\mathrm{LW}^{0.75}$ (Breirem, 1939) to $0.5^{8} \mathrm{MJ} / \mathrm{kg} \mathrm{LW} \mathrm{LW}^{0.75}$ (Sharma et al. 1971). The mean value of nine estimates (Breirem, 1939; Verstegen et al. 1973, Kotarbińska, 1969; Houseman \& McDonald, I973; Fuller \& Boyne, 1972; Holmes \& Breirem, 1974; Thorbek, 1975; Davies \& Lucas, I972; Sharma et al. 1971) is $0.45^{8} \mathrm{MJ} / \mathrm{kg} \mathrm{LW} \mathrm{W}^{0.75}$. Verstegen et al. (1973) suggest a 'best estimate' of 0.475 and Kielanowski (1976) 0.418 . The estimate used by Whittemore \& Fawcett (1976) (corrected for the energy costs of protein maintenance) of $0.475 \mathrm{LW}^{0.75}-0.365 \mathrm{Pt}$, by nature of the data from which it arose, remains equivocal.

Heat Production. Estimates for the efficiency of fat accretion range only from about 0.70 (Gädeken et al. 1974) to 0.78 (Burlacu et al. 1973); values from Thorbek (1975) and Kotarbińska (1969) being intermediate. An average of 0.74 gives a total (inclusive of heat of combustion of product) energy cost for fat accretion of $53.5 \mathrm{MJ} / \mathrm{kg} ; \mathrm{I4}_{4} .2 \mathrm{MJ}$ being lost as heat. Protein synthesis generates approximately $35 \mathrm{MJ}$ of heat $/ \mathrm{kg}$ protein accreted at $20 \mathrm{~kg}$ and $56 \mathrm{MJ}$ at $100 \mathrm{~kg}$, assuming the relationship described above for $\mathrm{Pr} / \mathrm{Px}$. Deamination adds another $4.9 \mathrm{MJ} / \mathrm{kg}$ protein. Heat production $(\mathrm{H})$ in a thermoneutral environment is therefore the sum of the heats of production from protein, fat and urea synthesis, together with the energetic costs of maintenance. Or, if calculated by difference, ME less the heats of combustion of protein and fat retained $(23.6 \mathrm{MJ}$ and 39.3 $\mathrm{MJ} / \mathrm{kg}$ respectively).

At environmental temperatures ( $\mathrm{T}$ ) below the lower critical temperature (Tc), additional increments of energy will be diverted, from productive processes (usually fat production), into heat generation $\left(\mathrm{H}^{1}\right.$, cold thermogenesis). Foregoing I kg of fat accretion releases $39.3 \mathrm{MJ}$ for heat production (not 53.5 , as $14.2 \mathrm{M}$ ) are foregone). Total heat production $(\hat{\mathrm{H}})$ is therefore the sum of $\mathrm{H}$ and $\mathrm{H}^{1}$.

Critical temperature $(\mathrm{Tc})$ depends upon the rate of heat production. For pigs accumulating constant amounts of fat and protein, maintenance determines variation in heat production, thus $\mathrm{Tc}$ is a function of live weight. Verstegen (197I) suggested $\mathrm{T} c=20-0.1 \mathrm{LW}$. This relationship requires to be modified by the effects 
of plane of nutrition; an increased level of feeding (and consequent rate of growth) causing a reduction in Tc (Verstegen et al. 1973; Holmes \& Close, 1976). Tc could be derived directly from $\mathrm{H}: \mathrm{Tc}=26.6-0.59 \mathrm{H}$, but for this derivation it was assumed that $\mathrm{H}$ was twice maintenance to enable transformation of a relationship based on live weight. Estimates of Tc by this equation are, however, in general agreement with those of Holmes \& Close (1976) from more sophisticated calculations.

Energy needed for cold thermogenesis has been estimated for pigs in groups of four to be between $\mathrm{II}$ and $16 \mathrm{~kJ}$ per degree difference between $\mathrm{T}$ and $\mathrm{Tc}$ per $\mathrm{kg}$ LW $W^{0.75}$ per day (Verstegen, 1971; Verstegen et al. 1973). Verstegen and van der Hel (1974) suggest $9 \mathrm{~kJ}$ for pigs in groups of nine. At any given $T$ an unfavourable environment increases the demand for heat production (H). It can, therefore, be considered as equivalent to a reduction in T. Air speed (Bond, Heitman \& Kelly, 1965) and floor insulation (Mount, 1968; Verstegen \& van der Hel, 1974) are particularly relevant. These factors, together with group size, have been brought together by Mount (1975), who described the thermal environment in terms of the air temperatures required to give a standard temperature of $14^{\circ}$. The range is from $22^{\circ}$ for an uninsulated, draughty environment, to $10^{\circ}$ for an unimpaired environment, together with a good straw bed. Verstegen $\&$ van der Hel suggest that pigs lying on concrete slats require an extra $4^{\circ}$ air temperature.

Not only is it apparent that $T$ has a significant effect upon growth and efficiency, but also that $T$ is an inadequate description of the environment for commercial pigs. Information on group size, air speed and floor insulation markedly improves the situation, but the total environment is more complex than can be described quantitatively by data presently available.

Ratio, fat:protein. Normal growth in the pig comprises a greater quantity of fat than protein. At $20 \mathrm{~kg}$ the whole empty body contains about $19 \%$ fat and $16 \%$ protein (Wood \& Groves, 1965); regression coefficients on empty body weight of 0.13 for lipid and 0.15 for protein have been determined at Edinburgh for 42-dayold pigs weaned at $14 \mathrm{~d}$. By $100 \mathrm{~kg}$ there is in the region of $30 \%$ fat and $13 \%$ protein. The water content of the body is inverse to that of fat; further, as the animal grows, the water associated with protein decreases. The relationship: Lean gain $(\mathrm{Mg})=\operatorname{Pr}(5 \cdot 1-0.009 \mathrm{LW})$ has been derived from Kotarbinska (1969) and shows how fat accumulates at the expense of both the protein-containing tissues and the water content of these tissues.

A description of fat growth as a function of energy supply is adequate if fat is regarded as an energy reserve, but inadequate if fat has a physiological role. There is limited evidence that the pig aspires to maintain a minimum level of fat in its body that is broadly equivalent to a $1: 1$ ratio with protein. Pigs in energy deficit may not continue to maximize protein accretion $(\mathrm{Pr})$ while retaining no fat; rather $\mathrm{Pr}$ is reduced pro rata to release energy for fat accretion (Lr). Wenk \& Schürch (1974) indicate that below the energy threshold which allows expression of $\mathrm{Pr}$, both $\mathrm{Lr}$ and $\mathrm{Pr}$ might be reduced; maintaining a ratio, $\mathrm{Lr}: \operatorname{Pr}$ of 1 -25:I. Pigs fed by Houseman \& McDonald (1973) to be excessively lean had ratios, fat:protein 
of about $0.8: 1$, and Kielanowski (1966b) suggested that even under severe feed limitation the ratio, Lr:Pr would be unlikely to be less than I:I. Should such a rate apply to accretion, it clearly does not to depletion. In energy deficit, fat stores may be broken down with no loss of protein; indeed the pig may simultaneously exhibit a negative value for $\mathrm{Lr}$ and a positive value for $\operatorname{Pr}$ (Thorbek, 1975). It is possible that the minimum $\mathrm{Lr}: \operatorname{Pr}$ may be related inversely to the ratio of total fat $(\mathrm{L} t)$ :total protein $(\mathrm{Pt})$ in the body. The minimum $\mathrm{I}: \mathrm{I}$ rule for $\mathrm{Lr}: \mathrm{Pr}$ is likely to apply most rigorously when $\mathrm{Lt}: \mathrm{Pt}$ is also unity. Under normal conditions, even for the production of lean pigs, the $I: I$ ratio is exceeded. However, the young pig over the growth phase $20-40 \mathrm{~kg}$ is particularly susceptible; $\mathrm{Lt}: \mathrm{Pt}$ will approximate unity and a limited appetite predisposes to an energy deficit. It is quite possible therefore that at live weights of below $40 \mathrm{~kg}, P \hat{r}$ is not attained in consequence of a physiological requirement for $\mathrm{Lr}$.

The minimum ratio for $\mathrm{Lr}: \mathrm{Pr}$ may differ according to degree of maturity, sex and genotype. Minimum body fatness becomes a function of the prevailing minimum for $\mathrm{Lr}: \operatorname{Pr}$ in conjunction with feed intake and Pr. Animals with a low appetite (or feed allowance) in relation to $P \hat{r}$ will follow the boundary dictated by the minimum value for the $\mathrm{Lr}: \operatorname{Pr}$ ratio; that is, the animal will not fatten. As appetite increases with weight or energy density of diet, or the feed allowance is raised, or $\operatorname{Pr}$ is reduced, then $L r>P \hat{r}$ and fattening begins.

The parameter Pr̂ denies compensation for growth of protein. This is not to say that $\operatorname{Pr}$ might not be elevated on realimentation; where $\overline{\operatorname{Pr}}<\operatorname{Pr}$, then $\operatorname{Pr}<\overline{\operatorname{Pr}}$ in one period, $\operatorname{Pr}>\overline{\operatorname{Pr}}$ may follow in apparent compensation. There is little evidence with which to ascertain the inviolate nature of Pr, despite the importance of this parameter to feeding strategy.

\section{REFERENCES}

Armstrong, D. G. (1969). In Handbuch der Tierernährung Vol. 1. p. $3^{85}$. [W. Lenkeit, K. Breirem \& E. Crasemann, editors] Hamburg: Paul Parey.

Bond, T. E., Heitman, H. \& Kelly, C. F. (1965). Trans. Am. Soc. agric. Engrs. 8, 167.

Breirem, K. (1939). Tierernährung $1 x, 487$.

Buriacu, G., Baia, G., Ionila, D., Moisa, D., Taşcenco, V., Vişan, I. \& Stoica, I. (1973). F. agric. Sci., Camb. 81, 295.

Buttery, P. J. \& Boorman, K. N. (1976). In Protein Metabolism and Nutrition, p. 197 [D. J. A. Cole, K. N. Boorman, P. J. Buttery, D. Lewis, R. J. Neale \& H. Swan, editors]. E.A.A.P. Publ. No. 16. London: Butterworths.

Close, W. H. \& Mount, L. E. (1975). Proc. Nutr. Soc. 34, 13 A.

Cöp, W. A. G. (1974). Meded Landb Hoogesch. Wageningen 74 (18)

Davies, J. L. \& Lucas, 1. A. M. (1972). Anim. Prod. 15, 111.

Fuller, M. F. \& Boyne, A. W. (1972). Br. Y. Nutr. 28, 373 .

Fuller, M. F., Yen, M. T. \& Lin, M. S. (1974). Proc. Br. Soc. Anim. Prod. 3, 86.

Gädeken, D., Oslage, H. J. \& Fliegel, H. (1974). In Energy Metabolism of Farm Animals, p. I69 [K. H. Menke, H. J. Lantzsch \& J. R. Reichl, editors]. E.A.A.P. Publ. No. 14. Hohenheim: Universität.

Graham, N. McC., Searle, T. W. \& Griffiths, D. A. (1974). Aust. J. agric. Res. 25, 957.

Holmes, C. W. \& Breirem, K. (1974). Anim. Prod. 18, 313.

Holmes, C. W. \& Close, W. M. (1976). In Proceedings of $X$ Nutrition Conference for Feed Manufacturers [W. Haresign \& H. Swan, editors]. London: Butterworths.

Houseman, R. A. \& McDonald, I. (r973). Anim. Prod. 17, 295.

Kielanowski, J. (1966a). Anim. Prod. 8, 121. 
Kielanowski, J. (1966b). In gth Intermational Congress of Animal Production, p. 212 . Edinburgh: Oliver \& Boyd.

Kielanowski, J. (rg69). Rota cubana Cienc. agric. 3, 207.

Kielanowski, J. (1972). In Pig Production, p. 183 [D. J. A. Cole, editor]. London: Butterworths.

Kielanowski, J. (1976). In Protein Metabolism and Nutrition, p. 207 [D. J. A. Cole, K. N. Boorman, P. J. Buttery, D. Lewis, R. J. Neale \& H. Swan, editors]. E.A.A.P. Publ. No. 16. London: Butterworths.

Kielanowski, J. \& Kotarbinska, M. (1970). In Energy Metabolism of Farm Animals. Proceedings 5th Symposium, Viznau, p. 145 [A. Schürch \& C. Wenk, editors]. E.A.A.P. Publ. No. 13. Zürich: Juris Druck.

Kotarbinska, M. (1969). Badania nad Prxemiana Energii u Rosnacych swin Instytut Zootechniki, Wroclaw.

Lubaszewska, S., Pastuszewska, B. \& Kielanowski, J. (1973). Z. Tierphysiol. Tieremähr. Futtermittelk. 31, 120.

Meat and Livestock Commission. (1975). Product Evaluation Report. Meat and Livestock Commission. Bletchley.

Miller, D. S. \& Payne, P. R. (1963). F. theor. Biol. $5,398$.

Millward, D. J., Garlick, P. J., James, W. P. T., Sender, P. M. \& Waterlow, J. C. (1976). In Protein Metabolism and Nutrition, p. 49 [D. J. A. Cole, K. N. Boorman, P. J. Buttery, D. Lewis, R. J. Neale \& H. Swan, editors]. E.A.A.P. Publ. No. 16. London: Butterworths.

Møllgaard, H. (1955). Methods of quantitative determination of growth. 282 Beretn. Forsogslab. København.

Mount, L. E. (1968). The Climatic Physiology of the Pig. London: Edward Amold.

Mount, L. E. (1975). Livestk Prod. Sci. 2, $3^{81}$.

Mount, L. E. \& Holmes, C. W. (1969). In Energy Metabolism of Farm Animals, p. 3 I I [K. L. Blaxter, J. Kielanowski \& G. Thorbek, editors]. E.A.A.P. Publ. No. 12. Newcastle-upon-Tyne: Oriel Press.

Müller, H. L. \& Kirchgessner, M. (1974). In Energy Metabolism of Farm Animals, p. 185 [K. H. Menke, H. J. Lantzsch \& J. R. Reichl, editors]. E.A.A.P. Publ. No. 14. Hohenheim: Universität.

Okwuosa, B. N. (1971). Ph.D. Thesis. University of Leeds.

Oslage, H. J. \& Fliegel, H. (1965). In Energy Metabolism Proc. 3rd Symposium, Troon, p. 297 [K. L. Blaxter, editor]. E.A.A.P. Publ. II. London: Academic Press.

Oslage, H. J., Fliegel, H., Farries, F. E. \& Richter, K. (Ig66). Z. Tierphysiol. Tierernähr. Futtermittelk. 21, 50 .

Piatkowski, B. \& Jung, H. (1966). Arch. Tierx. 9, 307.

Rèrat, A. (1972). Nutr. Abstr. Reo. 42, 13.

Rérat, A. \& Henry, Y. (1964). Annls Zootech. 13, 5.

Sharma, V. D., Young, L. G. \& Smith, G. C. (1971). Can. F. Anim. Sci. 51, 76r.

Thorbek, G. (1974). In Energy Metabolism of Farm Animals, p. 147. [K. M. Menke, H. J. Lantzsch \& J. R. Reichl, editors]. E.A.A.P. Publ. No. 14. Hohenheim: Universität.

Thorbek, G. (1975). Studies on energy metabolism in growing pigs II. 424 Beretn. St. Husdyrbrugsforseg, København.

Velu, J. G. \& Baker, D. H. (1974). Poult. Sci. 53, 1831 .

Verstegen, M. W. A. (1971). Meded Landb Hoogesch. Wageningen, 7 I (2).

Verstegen, M. W. A., Close, W. H. Start, I. B. \& Mount, L. E. (1973). Br. J. Nutr. 30, 21.

Verstegen, M. W. A. \& van der Hel, W. (1974). Anim. Prod. 18, I.

Wenk, C. \& Schürch, A. (1974). In Energy metabolism of farm animals, p. 173 [K. H. Menke, H. J. Lantzsch \& J. R. Reichl, editors]. E. A.A.P. Publ. No. 14. Hohenheim: Universität.

Whittemore, C. T. (1976). Praceedings of Symposium on Computer Use in Feed Formulation. Brussels: N.R.A.

Whittemore, C. T. \& Elsley, F. W. H. (1976). Practical Pig Nutrition. Ipswich: Farming Press Ltd.

Whittemore, C. T. \& Fawcett, R. H. (1974). Anim. Prod. 19, 221.

Whittemore, C. T. \& Fawcett, R. H. (1975a). Proceedings of Seminar on Computer Optimisation of Pig Feeding Programmes: University of Edinburgh.

Whittemore, C. T. \& Fawcett, R. H. (1975b). Proc Br. Soc. Anim. Prod. 4, 116.

Whittemore, C. T. \& Fawcett, R. H. (1976). Anim. Prod. 22, 87.

Wood, A. J. \& Groves, T. D. D. (1965). Can. J. Anim. Sci. $45,8$.

\section{Printed in Great Britain}

